\title{
Childhood Leiomyosarcoma
}

National Cancer Institute

\section{Source}

National Cancer Institute. Childhood Leiomyosarcoma. NCI Thesaurus. Code C8093.

An aggressive malignant smooth muscle neoplasm, occurring in children. It is

characterized by a proliferation of neoplastic spindle cells. 